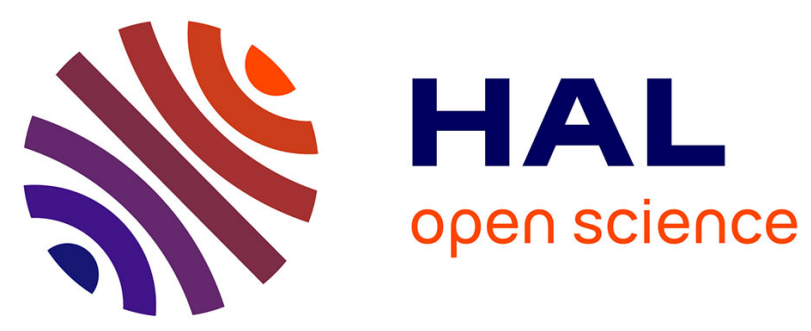

\title{
Bulky DNA adducts and breast cancer risk in the prospective EPIC-Italy study
}

Calogero Saieva, Marco Peluso, Giovanna Masala, Armelle Munnia, Marco

Ceroti, Sara Piro, Francesco Sera, Benedetta Bendinelli, Valeria Pala, Sabina

Sieri, et al.

\section{To cite this version:}

Calogero Saieva, Marco Peluso, Giovanna Masala, Armelle Munnia, Marco Ceroti, et al.. Bulky DNA adducts and breast cancer risk in the prospective EPIC-Italy study. Breast Cancer Research and Treatment, 2011, 129 (2), pp.477-484. 10.1007/s10549-011-1472-8 . hal-00628287

\section{HAL Id: hal-00628287 \\ https://hal.science/hal-00628287}

Submitted on 1 Oct 2011

HAL is a multi-disciplinary open access archive for the deposit and dissemination of scientific research documents, whether they are published or not. The documents may come from teaching and research institutions in France or abroad, or from public or private research centers.
L'archive ouverte pluridisciplinaire HAL, est destinée au dépôt et à la diffusion de documents scientifiques de niveau recherche, publiés ou non, émanant des établissements d'enseignement et de recherche français ou étrangers, des laboratoires publics ou privés. 


\title{
Bulky DNA adducts and breast cancer risk in the prospective EPIC-Italy study
}

\author{
Authors \\ Calogero Saieva ${ }^{1 *}$, Marco Peluso $^{2 *}$, Giovanna Masala ${ }^{1}$, Armelle Munnia ${ }^{2}$, Marco Ceroti $^{1}$, \\ Sara Piro ${ }^{2}$, Francesco Sera ${ }^{1}$, Benedetta Bendinelli ${ }^{1}$, Valeria Pala $^{3}$, Sabina Sieri ${ }^{3}$, \\ Rosario Tumino ${ }^{4}$, Maria Concetta Giurdanella ${ }^{4}$, Salvatore Panico ${ }^{5}$, Amalia Mattiello ${ }^{5}$, \\ Paolo Vineis ${ }^{6,7}$, Silvia Polidoro ${ }^{8}$, Giuseppe Matullo ${ }^{9,10}$ and Domenico Palli ${ }^{1}$ \\ * These authors equally contributed to this work
}

\author{
Affiliation \\ ${ }^{1}$ Molecular and Nutritional Epidemiology Unit and ${ }^{2}$ Cancer Risk Factor Branch, Molecular \\ Biology Laboratory, ISPO (Cancer Research and Prevention Institute), Florence, Italy; \\ ${ }^{3}$ Nutritional Epidemiology Unit, Fondazione IRCCS Istituto Nazionale Tumori, Milan, Italy; \\ ${ }^{4}$ Cancer Registry, ‘Civile M.P. Arezzo’ Hospital, ASP 7, Ragusa, Italy; \\ ${ }^{5}$ Department of Clinical and Experimental Medicine, Federico II University, Naples, Italy; \\ ${ }^{6}$ Cancer Epidemiology Unit, University of Turin, Turin, Italy; \\ ${ }^{7}$ Department of Epidemiology and Public Health, Imperial College, London, UK; \\ ${ }^{8}$ Human Genetics Foundation (HuGeF), Turin, Italy; \\ ${ }^{9}$ Department of Genetics, Biology and Biochemistry, University of Turin, Turin, Italy; \\ ${ }^{10}$ Institute for Scientific Interchange Foundation, Turin, Italy
}

\section{Corresponding Author}

Domenico Palli, MD

Molecular and Nutritional Epidemiology Unit, ISPO

Via Cosimo il Vecchio 2, 50139 Florence;

Phone +39055 32697 828;

Fax +39 05532697 829;

E-mail: d.palli@ispo.toscana.it 


\section{Abstract}

The role of environmental carcinogen exposure in breast cancer development has long been suspected, but no specific association has been identified so far. A few molecular epidemiology studies reported that DNA adducts detected by different methods are associated with a modest increase of breast cancer risk. We aimed to evaluate the association between bulky DNA adducts, detected by the ${ }^{32} \mathrm{P}$-postlabelling method in peripheral leukocytes, and the risk of developing breast cancer in the female Italian cohorts of the EPIC (European Prospective Investigation into Cancer and nutrition) study.

By using a nested case-control design, breast cancer cases identified in the follow-up of over 30,000 women of EPIC-Italy study have been matched to controls by specific criteria. We measured the levels of bulky DNA adducts by the ${ }^{32} \mathrm{P}$-postlabelling method in peripheral leukocytes donated at enrolment. Conditional regression analyses adjusted for selected potential confounders were used.

Results on DNA adduct levels were available for 292 cases and 292 matched controls. The mean DNA adduct levels were similar in both groups $(\mathrm{p}=0.62)$. Multivariate regression analyses failed to show any significant association between bulky DNA adducts and breast cancer.

Our results do not support any association of breast cancer risk with exposure to environmental carcinogens as measured through the levels of bulky DNA adducts in pre-diagnostic white blood cells. Larger studies by using different methods and/or biomarkers are needed be better evaluate the role of specific environmental carcinogens in breast carcinogenesis.

\section{Key words}

DNA adducts, breast cancer, case-control study, nested design, follow-up. 


\section{Introduction}

Breast cancer (BC) is by far the most frequent diagnosed cancer worldwide among women in 2008, and is the most frequent cause of cancer death in women in both developing and developed regions [1]. Also in Italy, according to recent data of the Italian Network of Cancer Registries for the period 2003-2005, BC is the most frequent cancer and the first cause of cancer death in the female population [2].

As with most other human cancers, the occurrence of $\mathrm{BC}$ is related to both individual host and environmental factors [3]. While individual factors related to reproductive history and hormonal status are well known, the role of environmental carcinogen exposure in BC development has not been well defined [4].

Previous studies of small size have reported that breast tissue samples obtained from women with BC have a significantly higher level of DNA adducts, detected by ${ }^{32} \mathrm{P}$-postlabelling or immunoassay methods, in comparison to those obtained from controls [5-8]. Recently, a modest support for an association between DNA adducts, detected by ELISA method, and BC development has been reported by a larger population-based study [9], and by a pooled analysis [10].

Several chemical compounds, such as polycyclic aromatic hydrocarbons (PAHs), and other aromatic compounds to which there is a wide human exposure, have been shown experimentally to cause mammary cancers in laboratory animals and to bind to DNA in breast epithelial cells, thus forming DNA adducts [11-14]. When unrepaired, DNA adducts can cause mutations, including mutational hotspots in the p53 tumor suppressor gene and other genes which may ultimately induce cancer development [15].

Different methods may be used to measure DNA adducts in human tissues. The ${ }^{32} \mathrm{P}$-postlabelling method, widely applied because of its high sensitivity and the requirement for only microgram amounts of DNA, typically detects a mixture of adducts often referred to as aromatic or bulky adducts [16]. However, it is virtually impossible to determine the structure of the labelled adduct detected by this approach and based on the resulting chromatographic spots or high-performance liquid chromatography peaks [16]. Bulky DNA adducts represent markers of exposure to different carcinogenic aromatic compounds, and of the individual ability to metabolically activate carcinogens and to repair DNA damage, and may be considered as markers of cancer risk [17]. Some studies have reported that cancer cases at different site (lung, bladder, oral cavity) have higher bulky DNA adduct levels than controls [18-20]. In other studies, this difference was influenced by smoking history, being more evident only in current-smokers [21-24], or in never-smokers [25]. On the other hand, one study did not support any association between bulky DNA adducts and bladder cancer risk [26]. 
The aim of the current study was to evaluate the association between bulky DNA adducts, detected by the ${ }^{32} \mathrm{P}$-postlabelling method in peripheral leukocytes, and the risk of developing BC in the Italian female cohort of the EPIC (European Prospective Investigation into Cancer and nutrition) study.

\section{Materials and Methods}

EPIC-Italy

The Italian section of the large European project on diet and cancer known as EPIC [27] is based on 47,749 volunteers of both sexes, with 32,578 women, aged 35-64 years, enrolled in 5 centers across different areas of the country: Varese and Turin in the Northern part of the country, Florence in Central Italy and Ragusa and Naples in Southern Italy. Recruitment of volunteers was carried out in the period January 1993 - March 1998. After the signature of an informed consent, at enrolment weight, height, waist and hip circumferences were measured for each participant, according to an international study protocol. Detailed individual information has been collected on lifestyle habits by a standardised lifestyle questionnaire, and on dietary habits by a Food Frequency Questionnaire specifically developed for the Italian dietary habits [28].

\section{Blood collection and storage}

For each participant a blood sample was collected according to a standardized protocol, and has been processed by centrifugation on the same day of collection, and divided into 28 aliquots [27]. The aliquots have been stored in liquid nitrogen tanks at $-196^{\circ} \mathrm{C}$ in the local EPIC biological banks and centrally at IARC, Lyon.

\section{Follow-up for cancer incidence and state in life}

Incident BC cases were identified through record linkage with local Cancer Registries and medical records of the main local hospitals. In all study centres each BC diagnosis was confirmed by a comprehensive review of pathology reports that followed a detailed protocol for the collection and standardization of clinical and pathological data. Information on the state in life were collected from local Mortality Registries. The end of the study period was defined as the latest date of complete follow-up for both cancer incidence and vital status (overall, 31 December 2001). 


\section{Selection of Study Subjects}

Study subjects (cases and controls) were selected among women who at blood donation reported that they did not use exogenous hormones for contraception or medical purposes and who had not been previously diagnosed with cancer (except for non-melanoma skin cancer). 'Cases' were women who developed BC after they were enrolled into the EPIC study and before the end of the study period. For each BC case patient, up to two 'controls' were chosen at random among appropriate risks sets consisting of all cohort members alive and free of cancer (except for non-melanoma skin cancer) at the time of diagnosis of the index case. Matching characteristics included the study centre where the subjects were enrolled in the cohort, age at blood donation ( \pm 6 months) and menopausal status (premenopausal or postmenopausal). A total of 295 BC cases and 295 matched controls were included in the present study, and their samples were retrieved from the project biological bank. A few samples were not available for DNA analysis, and 3 matched sets were excluded. DNA adduct levels were available for $292 \mathrm{BC}$ cases and their 292 matched controls.

\section{DNA extraction and ${ }^{32} P$-postlabelling DNA assay}

Leukocyte DNA was isolated and purified from stored buffy coats by enzymatic digestion of RNA and proteins followed by phenol chloroform extractions [29]. DNA adducts were measured using the nuclease P1 ${ }^{32}$ P-DNA post-labelling technique, a method mainly effective at detecting bulky DNA adducts [16]. The detection limit used was 0.1 adduct per $10^{9}$ normal nucleotides, as previously reported [29]. The levels of DNA adducts are expressed as Relative Adduct Labelling (RAL) values. The reproducibility of the ${ }^{32} \mathrm{P}-\mathrm{DNA}$ postlabelling technique was verified analysing approximately $20 \%$ of DNA samples with a second independent experiment and the results of the two analyses were in good agreement $(r=0.98)$. Further validation data have been previously reported [30]. All the analyses were carried out blindly prior to decoding.

\section{Statistical analyses}

DNA adduct levels were expressed as mean $( \pm \mathrm{SD})$ of the RAL values, and were analyzed as continuous and categorical variables. To normalize the distribution of DNA adduct measurements, we performed analyses by using also log-transformed data. However, because results did not differ substantially, only results based on original data are here presented. Negative samples (those below 0.1 adduct $/ 10^{9}$ normal nucleotides, the threshold of detection of the method) were arbitrarily assigned a value of 0.1 . We dichotomized DNA adducts into 'undetectable' and 'detectable' values according to the above-mentioned detection limit. The detectable 
samples we also classified into tertiles. Finally, we used the median value of RAL to divide DNA adducts into two groups (below and above the median).

Statistical significance of case-control differences in selected variables was evaluated by paired comparisons (t-tests) of case values versus the control values, in each case-control set. For categorical variables, a chi-square test was used. We have explored the relationship between DNA adduct levels and the BC risk with conditional regression models adjusting for potential confounders. Particularly, we have computed odd ratios (ORs) and 95\% confidence intervals (95\% CIs) in conditional regression models including terms for body mass index (BMI, $\mathrm{kg} / \mathrm{mt}^{2}$ ), smoking habits, education level, age at menarche, age at first delivery, and alcohol consumption. We used dummy variables to categorise some variables included in the models (over-weight, obese vs. normal weight; current-smoker, ex-smoker vs. never-smoker; secondary, professional, high school, university degree $v s$. no/primary school). The other parameters (age at menarche, age at first delivery and alcohol consumption) were included as continuous variables. We carried out separate models by using different reference categories (i.e., undetectable values, the first tertile of detectable values, the values below the median). Further analyses were performed by using unconditional logistic models including also the matching variables.

Cigarette smoking has been reported as important contributor to body levels of DNA adducts, particularly PAH-DNA adducts [31]. This factor is, therefore, considered as antecedent in the causal pathway for BC development [9], and might not be included in the multivariate model performed to adjust for potential confounding. On the other hand, our previous studies did not report any significant association between smoking history and bulky DNA adducts [32,33]. Thus, we included smoking habits as covariate in our regression models. But, we performed further statistical analyses by excluding smoking habits from the regression models, and by evaluating the association between DNA adducts and BC risk in each category of exposure according to the smoking habit (current-, ex- and never-smoker).

Finally, other analyses were performed in each category of exposure according to the menopausal status (pre- and post-menopause).

A $p$ value less than 0.05 was considered significant. All the analyses were performed by the statistical package SAS (version 9.1 for Windows). 


\section{Results}

Bulky DNA adducts were detected in $88.9 \%$ of the tested samples (257 cases and 262 controls, from 292 matched sets), while 65 samples (35 cases and 30 controls) resulted negative, i.e. with a DNA adduct level below the detection limit.

Table 1 shows the mean values $( \pm \mathrm{SD})$ of DNA adduct levels for cases and controls, overall and according to selected individual characteristics. The mean DNA adduct levels per $10^{9}$ nucleotides (and corresponding SD) were $10.41( \pm 13.8)$ for cases and $10.96( \pm 12.6)$ for controls. The observed difference in the mean values between the two groups was not statistically significant $(\mathrm{p}=0.62)$. The median (and range) for cases and controls were $6.3(0.1-109.8)$ and $7.45(0.1-102.3)$ per $10^{9}$ nucleotides, respectively. The plot of the distribution of DNA adducts levels in the two groups of subjects is reported in Fig. 1.

No significant differences of DNA adduct levels were found between cases and controls in separate strata according to EPIC centre, BMI and smoking history categories (Table 1). Within older women according to the age at blood donation (over the median, 52+ years), a borderline effect emerged with lower DNA adduct levels in cases than in controls ( $\mathrm{p}=0.05$ ). In the stratum of post-menopausal women, a significant difference between cases and controls was found, with significantly lower DNA adduct levels in cases $(\mathrm{p}=0.02)$. A difference in the same direction was suggested in obese women $(\mathrm{p}=0.11)$. Within both cases and controls, DNA adduct levels varied significantly between the EPIC centres ( $\mathrm{p}=0.03$ and $\mathrm{p}=0.0004$, respectively), with the lowest values in Ragusa in both groups, and highest values in Turin among BC cases and in Naples among controls.

Among BC cases, but not among controls, DNA adduct levels were significantly lower in postmenopausal compared to pre-menopausal women ( $\mathrm{p}=0.008$ ). DNA adduct levels tended also to be lower among older ( $\mathrm{p}=0.06)$, obese and never-smoker cases. When we compared current- smokers with non smokers (ex- and never-smokers combined), we found a significant difference with higher levels in current-smokers ( $\mathrm{p}=0.049)$. Among the controls, no significant differences emerged according to age, menopausal status, BMI and smoking history.

Table 2 shows the adjusted ORs for BC (and 95\% CIs) in relation to DNA adduct levels by separate conditional regression models by using different reference categories. Particularly, the adjusted OR for BC in relation to detectable DNA adducts as compared with undetectable levels was 1.14 (model 1). When DNA adducts were considered as a continuous variable (model 2), the OR was 1.00 for each increasing unit. The model 3 showed the adjusted OR for BC in relation to DNA adduct levels categorized in tertiles, with all 
undetectable samples placed in the referent category. The model showed no significant association between DNA adduct levels and BC risk, nor an increasing risk with increasing adduct levels. In the model 4 we used the first tertile of the detectable samples as referent category, reporting a lack of association between DNA adduct levels and BC risk. Finally, the model 5 by using the dichotomic variable according to RAL median value (7.65) did not reports any significant association between DNA adducts and BC risk.

Further analyses were performed by using unconditional logistic models including also the matching variables, i.e. age at blood donation (in continuum), menopausal status (pre/post menopause) and centre of enrolment. Results from these latter models were similar to the conditional regression models, and were not reported. In particular, in the analyses with the series restricted only to subjects with detectable samples, by model 2, we obtained similar results (OR=1.01, 95\% CI: 0.99-1.02).

Conditional regression models without smoking habits as covariate did not show any significant results about association between DNA adducts and BC risk (data not shown). Likewise, no significant results emerged by conditional regression models carried out in each category of exposure according to the smoking habit (data not shown).

Finally, no significant results were found by unconditional logistic models carried out separately in preand post-menopausal women, and including also the other matching variables (age at blood donation and centre of enrolment) (data not shown).

\section{Discussion}

In this study we examined the association between bulky DNA adducts detected by the ${ }^{32} \mathrm{P}$-postlabelling method in peripheral leukocytes and the risk of developing BC in the female Italian cohort of the EPIC study. Overall, no significant difference in DNA adduct levels emerged between cases and their matched controls. Conditional regression analyses adjusted for selected potential confounders did not show any significant association between DNA adduct levels and BC risk. Thus, our results provide no evidence that bulky DNA adducts measured in peripheral leukocytes are associated with $\mathrm{BC}$ risk.

Overall, our results are in disagreement with those reported by some previous studies showing a modest increase in BC risk related to DNA adducts [5-8]. There are some differences between ours and the abovementioned studies, particularly a different study design. Case-control studies, such as those cited above, are by their retrospective nature limited in their ability to establish causality of environmental factors: in 'case-control' studies the biomarker may reflect the disease rather than the aetiology. On the other hand, the major strength of 
our study is its prospective design: we carried out a 'nested' case-control study within a prospective study so the measurement of DNA-adducts in peripheral leukocytes was based on blood samples collected well before cancer diagnosis, thus ruling out the possibility that the higher adduct levels were due to changes related to the presence of cancer. An additional strength of our study is the relatively large sample size. We evaluated the DNA adduct levels in 292 matched samples (each with one BC case and her matched control), while the previous studies [5-8] were based on a smaller number of samples. Only the Long Island Breast Cancer Study Project (LIBCSP) [9, 10] was based on a larger series, with 575 cases and 424 controls, but it used a different method for the detection of DNA adducts, i.e. the ELISA technique that resulted to be less sensitive than the ${ }^{32} \mathrm{P}$-postlabelling method used in our study but, on the other hand, selective for PAH-DNA adducts.

To detect DNA adducts we used ${ }^{32} \mathrm{P}$-postlabelling method like some previous studies $[5,6,8]$, but unlike others $[7,9,10] .{ }^{32} \mathrm{P}$-postlabelling and immunoassays are the most widely methods used for the detection of carcinogen-DNA adducts. At a certain level, these two methods are not comparable due to only partial overlapping of their substrate specificities [34]. The ${ }^{32} \mathrm{P}$-postlabelling method has the advantage of high sensitivity for bulky DNA adducts typically formed from aromatic compounds [16, 34, 35], but is not suitable for the identification of specific DNA adduct structures. The immunoassay method, using antisera elicited against DNA modified with benzo( $\alpha$ )pyrene, recognize chemically related PAH-DNA adduct structures due to cross-reactivity of the antibody. Furthermore, immunoassays are influenced by the binding efficiency and crossreactivity of the DNA adducts, whereas ${ }^{32} \mathrm{P}$-postlabelling is not always successful in labelling all the available adducts and there is a tendency for underestimation [34].

Thus, we are unable to specify the exact composition of the detected adducts for subtype analysis. In a previous study carried out in the frame of EPIC-Florence study, by using the same method of DNA adducts detection $\left({ }^{32} \mathrm{P}\right.$-postlabelling), we reported a significant correlation between individual levels of bulky DNA adducts and the mean environmental levels of a specific air pollutant (ozone), measured in a period prior the blood drawing, in never-smokers residing in the Florence urban area and not occupationally exposed to vehicle traffic pollution [36]. The association between bulky DNA adducts and ozone concentration has been confirmed in a larger nested case-control study carried out in the frame of a larger European prospective study [25]. In a previous study we also reported that the average concentrations of particulate matter (based on $\mathrm{PM}_{10}$ ), estimated at high-traffic locations, may predict the levels of DNA bulky adducts but only in a specific category represented by never-smoker traffic-exposed workers in the Florence urban area [37]. A recent pooled analysis including 3,600 subjects in which bulky DNA adducts were measured in white blood cells with similar ${ }^{32} \mathrm{P}$-postlabelling 
techniques showed weak associations between bulky DNA adducts and exposure variables, and reported that seasonality and air pollution may partly explain some of the inter-area differences in DNA adduct levels across European countries, with higher mean values in Southern Europe [38]. This trend corresponds to the different levels of $\mathrm{PM}_{10}$ and $\mathrm{NO}_{2}$ observed across Europe [38].

Another difference between ours and other studies is related to the type of sample used to evaluate DNA adduct levels. We used peripheral leukocytes, while the above-mentioned studies used breast tissue samples [5-8], except the LIBCSP evaluating peripheral mononuclear cells [9, 10]. There are conflicting data regarding the relationship between DNA adduct formation in target and surrogate tissues, although recent studies have reported a significant correlation between the levels of DNA adducts detected in peripheral tissue (blood) and target tissues (bronchus, lung) [34, 39] showing thus that peripheral blood cells may be a valid surrogate tissue for estimating the burden of DNA adducts in target tissue. However, specific data about the correlation between DNA adducts detected in blood and breast tissue are not available.

Furthermore, we were unable to determine the specific contributions of all the possible exposure sources, both past and present, to the DNA adducts measured on leukocytes. Our analyses have not included environmental, nutritional and genetic factors, and we did not consider possible gene-environmental interactions that might help explain the variability in individual DNA adduct levels and BC risk. The lack of association between DNA adducts and BC risk found in our series might reflect the variability in individual susceptibility, i.e. in DNA repair or specific metabolic pathways. Several parameters have been reported to influence the levels of DNA adducts, such as age, gender, BMI, physical activity, consumption of charcoal-broiled food, fresh fruit and vegetables, and genetic susceptibility [40]. However, our multivariate statistical analyses included as covariates several individual characteristics, besides the matching variables. Overall, a significant difference between cases and controls was found only in the sub-group of post-menopausal women, with lower values in cases than in controls. Similar differences were also suggested in the strata of older and obese women. In analyses carried out among cases, we also found that DNA adduct levels were significantly lower in postmenopausal women, and tended to be lower among older, obese subjects, and those not smoking at the time of blood donation. In contrast, the controls showed a more limited variability of DNA adduct levels. The meaning of this pattern of associations restricted to cases (healthy women who later developed BC) is unclear and warrants further investigations.

On the other hand, we found that DNA adduct levels varied significantly according to the geographical area, with the lowest values in Ragusa, a small town in Sicily, in both cases and controls. These results are in 
agreement with our previous studies $[32,33]$ reporting a difference on DNA adduct levels according to the EPIC centre with the lowest levels in Ragusa. These differences might be due to specific factors such as the variability in dietary and/or lifestyle habits, or in individual susceptibility, or more probably to differences in vehicle-traffic and photochemical pollution. We can reasonably exclude a laboratory bias because all samples have been analysed in mixed batches in a single study laboratory.

In conclusion, our relatively large nested case-control study carried-out in the frame of the EPIC-Italy study does not support an association between bulky DNA adduct levels measured on peripheral leukocytes by the ${ }^{32} \mathrm{P}$-postlabelling method and development of BC. Larger studies by using different methods and/or biomarkers are needed be better evaluate the role of specific environmental carcinogens in breast carcinogenesis.

\section{Conflict of interest}

None of the authors had any conflict of interest to declare. 


\section{References}

1. Ferlay J, Shin HR, Bray F, Forman D, Mathers C, Parkin DM (2010) Estimates of worldwide burden of cancer in 2008: GLOBOCAN 2008. Int J Cancer. doi:10.1002/ijc.25516

2. AIRT Working Group (2009) New incidence and mortality data 2003-2005. Epidemiologia \& Prevenzione 33 (Suppl 2): e6

3. Firozi PF, Bondy ML, Sahin AA, Chang P, Lukmanji F, Singletary ES, et al (2002) Aromatic DNA adducts and polymorphisms of CYP1A1, NAT2, and GSTM1 in breast cancer. Carcinogenesis 23(2):301-306

4. Janet Gray (2008) State of the Evidence 2008: The Connection between Breast Cancer and the Environment. New York, USA

\section{Perera FP, Estabrook A, Hewer A, Channing K, Rundle A, Mooney LA, et al (1995) Carcinogen-DNA} adducts in human breast tissue. Cancer Epidemiol Biomarkers Prev 4(3):233-238

6. Li D, Wang M, Dhingra K, Hittelman WN (1996) Aromatic DNA adducts in adjacent tissues of breast cancer patients: clues to breast cancer etiology. Cancer Res 56:287-293

7. Rundle A, Tang D, Hibshoosh H, Estabrook A, Schnabel F, Cao W, et al (2000) The relationship between genetic damage from polycyclic aromatic hydrocarbons in breast tissue and breast cancer. Carcinogenesis 21(7):1281-1289

8. Li D, Walcott FL, Chang P, Zhang W, Zhu J, Petrulis E, et al (2002) Genetic and environmental determinants on tissue response to in vitro carcinogen exposure and risk of breast cancer. Cancer Res 62:4566-4570

9. Gammon MD, Santella RM, Neugut AI, Eng SM, Teitelbaum SL, Paykin A, et al (2002) Environmental toxins and breast cancer on Long Island. I. Polycyclic aromatic hydrocarbon DNA adducts. Cancer Epidemiol Biomarkers Prev 11:677-685

10. Gammon MD, Sagiv SK, Eng SM, Shantakumar S, Gaudet MM, Teitelbaum SL, et al (2004) Polycyclic aromatic hydrocarbon-DNA adducts and breast cancer: a pooled analysis. Arch Environ Health 59:640-649

11. el-Bayoumy K (1992) Environmental carcinogens that may be involved in human breast cancer etiology. Chem Res Toxicol 5(5):585-590

12. Mane SS, Purnell DM, Hsu IC (1990) Genotoxic effects of five polycyclic aromatic hydrocarbons in human and rat mammary epithelial cells. Environ Mol Mutagen 15(2): 78-82

13. Eldridge SR, Gould MN, Butterworth BE, Eldridge SR, Gould MN, Butterworth BE (1992) Genotoxicity of environmental agents in human mammary epithelial cells. Cancer Res 52(20): 5617-5621 
14. Calaf G, Russo J (1993) Transformation of human breast epithelial cells by chemical carcinogens. Carcinogenesis 14(3):483-492

15. Smith LE, Denissenko MF, Bennet WP, Li H, Amin S, Tang M. et al (2000) Targeting of lung cancer mutational hotspots by polycyclic aromatic hydrocarbons. J Natl Cancer Inst 92(10):803-811

16. Poirier MC (2004) Chemical-induced DNA damage and human cancer risk. Nat Rev Cancer 4(8):630-637

17.Vineis P. and Perera F (2000) DNA adducts as markers of exposure to carcinogens and risk of cancer. Int $\mathbf{J}$ Cancer 88:325-328

18. Li D, Wang M, Cheng L, Spitz MR, Hittelman WN, Wei Q (1996) In vitro induction of benzo(a)pyrene diol epoxide-DNA adducts in peripheral lymphocytes as a susceptibility marker for human lung cancer. Cancer Res $56(16): 3638-3641$

19. Peluso M, Airoldi L, Magagnotti C, Fiorini L, Munnia A, Hautefeuille A, et al (2000) White blood cell DNA adducts and fruit and vegetable consumption in bladder cancer. Carcinogenesis 21(2):183-187

20. Vulimiri SV, Wu X, Baer-Dubowska W, de Andrade M, Detry M, Spitz MR, et al (2000) Analysis of aromatic DNA adducts and 7,8-dihydro-8-oxo- 2'-deoxyguanosine in lymphocyte DNA from a case-control study of lung cancer involving minority populations. Mol Carcinog 27(1):34-46

21. Tang D, Phillips DH, Stampfer M, Mooney LA, Hsu Y, Cho S, et al (2001). Association between carcinogen-DNA adducts in white blood cells and lung cancer risk in the physicians health study. Cancer Res 61(18):6708-6712

22. Veglia F, Matullo G, Vineis P (2003) Bulky DNA adducts and risk of cancer: a meta-analysis. Cancer Epidemiol Biomarkers Prev 12(2):157-160

23. Bak H, Autrup H, Thomsen BL, Tjønneland A, Overvad K, Vogel U, et al (2006) Bulky DNA adducts as risk indicator of lung cancer in a Danish case-cohort study. Int J Cancer 118(7):1618-1622

24.Veglia F, Loft S, Matullo G, Peluso M, Munnia A, Perera F, et al (2008) DNA adducts and cancer risk in prospective studies: a pooled analysis and a meta-analysis. Carcinogenesis 29(5):932-936

25. Peluso M, Munnia A, Hoek G, Krzyzanowski M, Veglia F, Airoldi L, et al (2005) DNA adducts and lung cancer risk: a prospective study. Cancer Res 65(17):8042-8048

26. Castaño-Vinyals G, Talaska G, Rothman N, Alguacil J, Garcia-Closas M, Dosemeci M, et al (2007) Bulky DNA adduct formation and risk of bladder cancer. Cancer Epidemiol Biomarkers Prev 16(10):2155-2159. 
27. Palli D, Berrino F, Vineis P, Tumino R, Panico S, Masala G, et al (2003) A molecular epidemiology project on diet and cancer: the EPIC-Italy prospective study. Design and baseline characteristics of participants. Tumori $89: 586-593$

28. Pala V, Sieri S, Palli D, Salvini S, Berrino F, Bellegotti M, et al (2003) Diet in the Italian EPIC cohorts: presentation of data and methodological issues. Tumori 89:594-607

29. Reddy MV. and Randerath K (1986) Nuclease P1-mediated enhancement of sensitivity of 32P-postlabeling test for structurally diverse DNA adducts. Carcinogenesis 7:1543-1551

30. Peluso M, Hainaut P, Airoldi L, Autrup H, Dunning A, Garte S, et al (2005) Methodology of laboratory measurements in prospective studies on gene-environment interactions: the experience of GenAir. Mutat Res 574:92-104.

31. Santella RM, Grinberg-Funes RA, Young TL, Dickey C, Singh VN, Wang LW, et al (1992) Cigarette smoking related polycyclic aromatic hydrocarbon-DNA adducts in peripheral mononuclear cells. Carcinogenesis 13(11):2041-2045.

32. Palli D, Vineis P, Russo A, Berrino F, Krogh V, Masala G, et al (2000). Diet, metabolic polymorphisms and DNA adducts: the EPIC-Italy cross-sectional study. Int J Cancer 87:444-451

33. Palli D, Masala G, Peluso M, Gaspari L, Krogh V, Munnia A, et al (2004) The effects of diet on DNA bulky adduct levels are strongly modified by GSTM1 genotype: a study on 634 subjects. Carcinogenesis 25:577-584

34. Gyorffy E, Anna L, Kovacs K, Rudnai P and Schoket B (2008) Correlation between biomarkers of human exposure to genotoxins with focus on carcinogen-DNA adducts. Mutagenesis 23(1):1-18

35. Gyorffy E, Anna L, Gyori Z, Segesdi J, Minárovits J, Soltész I, et al (2004) DNA adducts in tumor, normal peripheral lung and bronchus, and peripheral blood lymphocytes from smoking and non-smoking lung cancer patients: correlations between tissues and detection by ${ }^{32} \mathrm{P}$-postlabelling and immunoassay. Carcinogenesis 25(7):1201-1209

36. Palli D, Saieva C, Grechi D, Masala G, Zanna I, Barbaro A, et al (2004). DNA bulky adducts in a mediterranean population correlate with environmental ozone concentration, an indicator of photochemical smog. Int. J. Cancer 109:17-23

37. Palli D, Saieva C, Munnia A, Peluso M, Grechi D, Zanna I, et al (2008) DNA adducts and PM10 exposure in traffic-exposed workers and urban residents from the EPIC-Florence City study. Sci Total Environ 403:105112. 
38. Ricceri F, Godschalk RW, Peluso M, Phillips D, Agudo A, Georgiadis PA, et al (2010) Bulky DNA adducts in white blood cells: a pooled analysis of 3600 subjects. Cancer Epidemiol Biomarkers Prev 19(12):3174-3181 39. Peluso M, Neri M, Margarino G, Mereu C, Munnia A, Ceppi M, et al (2004) Comparison of DNA adduct levels in nasal mucosa, lymphocytes and bronchial mucosa of cigarette smokers and interaction with metabolic gene polymorphisms. Carcinogenesis 25:2459-2465.

40. Vineis P, Husgafvel-Pursiainen K (2005) Air pollution and cancer: biomarker studies in human populations. Carcinogenesis 26:1846-1855. 
Caption Fig. 1 Plot of the distribution of DNA adducts levels in the two groups of study's subjects (292 breast cancer cases and 292 matched controls). The upper and the lower boundaries of the boxes are the upper and the lower quartiles. The box length is the interquartile distance so the box contains the middle $50 \%$ of values, the horizontal line inside the box indicate the median value. The vertical lines emanating from each box extend to highest and lower levels that are not outliers.

Table 1 Crude mean values of DNA adduct levels for 292 breast cancer cases and 292 matched controls, overall and according to selected individual characteristics.

\begin{tabular}{|c|c|c|c|c|}
\hline \multirow[b]{2}{*}{ Variable } & \multirow{2}{*}{$\begin{array}{c}\mathrm{N} . \\
\text { cases/controls }\end{array}$} & \multicolumn{2}{|c|}{ Mean (SD) DNA adduct levels ${ }^{\mathrm{a}}$} & \multirow[b]{2}{*}{ p-value ${ }^{b}$} \\
\hline & & cases & controls & \\
\hline Overall & $292 / 292$ & $10.41(13.8)$ & $10.96(12.6)$ & 0.62 \\
\hline \multicolumn{5}{|l|}{ EPIC-Italy Centre } \\
\hline \multicolumn{5}{|l|}{ Northern-Italy } \\
\hline Varese & $105 / 105$ & $9.68(12.8)$ & $10.58(9.5)$ & 0.56 \\
\hline Turin & $21 / 21$ & $18.59(14.8)$ & $13.57(10.7)$ & 0.21 \\
\hline \multicolumn{5}{|l|}{ Central-Italy } \\
\hline Florence & $109 / 109$ & 9.20 (13.6) & $8.48(10.7)$ & 0.68 \\
\hline \multicolumn{5}{|l|}{ Southern-Italy } \\
\hline Naples & $47 / 47$ & $12.37(17.3)$ & $17.5(10.1)$ & 0.19 \\
\hline Ragusa & $10 / 10$ & $\begin{array}{c}4.81(4.6) \\
p=0.03^{\mathrm{c}}\end{array}$ & $\begin{array}{l}5.64(1.6) \\
\mathrm{p}=0.0004^{\mathrm{c}}\end{array}$ & 0.60 \\
\hline \multicolumn{5}{|l|}{ Age at blood donation } \\
\hline$<52$ years & $142 / 140$ & $12.0(17.3)$ & $10.4(11.9)$ & 0.36 \\
\hline$\geq 52$ & $150 / 152$ & $\begin{array}{l}8.9(9.8) \\
p=0.06^{d}\end{array}$ & $\begin{array}{c}11.5(13.1) \\
\mathrm{p}=0.44^{\mathrm{d}}\end{array}$ & 0.05 \\
\hline \multicolumn{5}{|l|}{ Menopausal status } \\
\hline post-menopausal & $161 / 151$ & $\begin{array}{l}8.25(9.1) \\
\mathrm{p}=0.008^{\mathrm{d}}\end{array}$ & $\begin{array}{c}10.83(10.8) \\
\mathrm{p}=0.86^{\mathrm{d}}\end{array}$ & 0.02 \\
\hline \multicolumn{5}{|l|}{ BMI $\left(\mathrm{kg} / \mathrm{mt}^{2}\right)$} \\
\hline Normal $(<25)$ & $137 / 148$ & $11.53(15.3)$ & $11.8(12.8)$ & 0.84 \\
\hline Over-weight (25.1-29.9) & $108 / 103$ & $10.2(13.9)$ & $9.3(10.5)$ & 0.59 \\
\hline Obese $(30+)$ & $47 / 39$ & $\begin{array}{c}7.59(9.5) \\
p=0.25^{\mathrm{c}}\end{array}$ & $\begin{array}{c}12.17(16.2) \\
p=0.23^{\mathrm{c}}\end{array}$ & 0.11 \\
\hline \multicolumn{5}{|l|}{ Smoking history } \\
\hline Current-smoker & $63 / 82$ & $13.44(18.0)$ & $11.49(13.5)$ & 0.46 \\
\hline Ex-smoker & $64 / 53$ & $10.1(12.5)$ & $10.85(13.7)$ & 0.76 \\
\hline Never- smoker & $164 / 157$ & $\begin{array}{l}9.3(12.7) \\
\mathrm{p}=0.13^{\mathrm{c}}\end{array}$ & $\begin{array}{c}10.71(11.7) \\
\mathrm{p}=0.90^{\mathrm{c}}\end{array}$ & 0.30 \\
\hline
\end{tabular}

\footnotetext{
${ }^{\mathrm{a}} \mathrm{RALx} 10^{9}$

${ }^{\mathrm{b}} \mathrm{p}$-value from Mann-Whitney test or $\chi^{2}$ test as appropriate to evaluate the differences of mean adduct levels of each subgroup between cases and controls

${ }^{\mathrm{c}} \mathrm{p}$-value for chi-square for trend within cases or controls

${ }^{\mathrm{d}} \mathrm{p}$-value for the differences between separate categories within cases or controls
} 
Table 2 Adjusted ORs ${ }^{\mathrm{a}}$ for breast cancer and 95\%CI in relation to DNA adduct levels in a series of 292 breast cancer cases and 292 matched controls.

\begin{tabular}{|c|c|c|c|}
\hline Model & DNA adduct levels & p-value & OR $(95 \% C I)$ \\
\hline 1 & Detectable $v s$. undetectable & 0.64 & $1.14(0.67-1.93)$ \\
\hline 2 & Continuous scale & 0.63 & $1.00(0.98-1.01)$ \\
\hline 3 & $\begin{array}{l}\text { Undetectable } \\
\text { Tertile } 1 \text { of detectable } \\
\text { Tertile } 2 \\
\text { Tertile } 3\end{array}$ & $\begin{array}{c}- \\
0.84 \\
0.40 \\
0.48\end{array}$ & $\begin{array}{c}1^{\mathrm{b}} \\
1.06(0.59-1.90) \\
0.77(0.43-1.40) \\
0.81(0.45-1.46)\end{array}$ \\
\hline 4 & $\begin{array}{l}\text { Undetectable } \\
\text { Tertile } 1 \text { of detectable } \\
\text { Tertile } 2 \\
\text { Tertile } 3\end{array}$ & $\begin{array}{c}0.84 \\
- \\
0.17 \\
0.24\end{array}$ & $\begin{array}{c}0.94(0.53-1.69) \\
1^{\mathrm{b}} \\
0.73(0.46-1.14) \\
0.76(0.48-1.20)\end{array}$ \\
\hline 5 & $\begin{array}{l}\text { Undetectable } \\
\text { Below the median } \\
\text { Above median }\end{array}$ & $\begin{array}{c}0.86 \\
- \\
0.38\end{array}$ & $\begin{array}{c}1.05(0.60-1.83) \\
1^{b} \\
0.84(0.58-1.23)\end{array}$ \\
\hline
\end{tabular}

\footnotetext{
${ }^{a}$ by separate conditional regression models including terms for body mass index, smoking history, education level, age at menarche, age at first delivery and alcohol consumption. Each model differs in the variable describing the main determinant (DNA adducts) and the reference category.

${ }^{\mathrm{b}}$ : reference category in regression model
}

\section{Fig. 1}

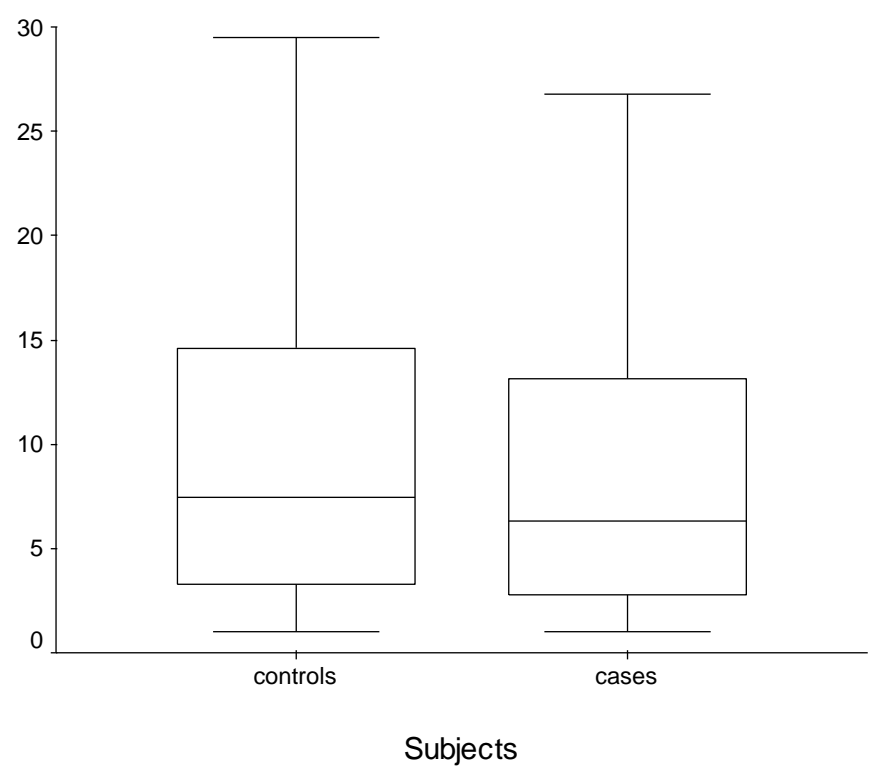

